\title{
Effect of condensation product of glycyl-glycine and furfural on electrodeposition of zinc from sulphate bath
}

\author{
H B MURALIDHARA, Y ARTHOBA NAIK* and T V VENKATESHA \\ Department of PG Studies and Research in Chemistry, School of Chemical Sciences, Kuvempu University, \\ Shankaraghatta 577 451, India
}

MS received 26 May 2006; revised 17 July 2006

\begin{abstract}
Zinc electrodeposition from sulphate bath was carried out in presence of condensation product formed between glycyl-glycine (GGL) and furfural (FFL). The bath constituents were optimized through Hull cell experiments. Operating parameters such as $\mathbf{p H}$, temperature and current density were also optimized. Current efficiency and throwing power were measured. Polarization study revealed shift of potential towards negative direction in the presence of addition agents. Corrosion resistance test revealed good protection of base metal by zinc coating obtained from developed electrolyte. SEM photomicrographs showed fine-grained deposit in the presence of condensation product. IR spectrum of the deposit showed inclusion of condensation product in the deposit during plating. The consumption of brightener in the lab scale was $7 \mathrm{mLL}^{-1}$ for 1000 amp-h.
\end{abstract}

Keywords. Electroplating of zinc; furfural; glycyl-glycine; Hull cell studies; sulphate bath.

\section{Introduction}

Electroplated zinc coatings are considered to be one of the main factors for the corrosion protection of steel. Cadmium has been extensively used as a barrier coating for steel in aerospace, electrical, and fastener industries owing to its excellent corrosion resistance and other engineering properties (Baldwin and Smith 1996). However, due to their high toxicity and hydrogen embrittlement properties, alternate coating to cadmium are being actively explored (Ashur et al 1996; Safranck 1997; Veeraraghavan et al 2003). The most commonly used sacrificial coating is zinc and its alloys. Zinc, by virtue of its low standard electrode potential $\left(E_{0}=-0.76 \mathrm{~V}\right.$ vs $\left.\mathrm{NHE}\right)$, acts as a sacrificial coating on steel (Swathirajan 1986). To give a thin electrocoating of zinc on steel, various baths are employed. Among these, sulphate baths are gaining importance because of their non-polluting nature (Arthoba Naik et al 2002). Organic additives are often used in electroplating operations in order to obtain smooth deposits, improved throwing power and satisfactory silvery gray appearance (Senthil Kumar et al 2001). To achieve this, combination of two or three, sometimes even more addition agents are used. Presence of many addition agents in the bath poses problem in determining the consumption of brightener during electroplating and some addition agents also cause pollution and health hazard (Arthoba Naik et al 2001; Arthoba Naik and Venkatesha 2005).

*Author for correspondence (drarthoba@yahoo.co.in)
In the present work, efforts have been made to develop a bath solution containing a single addition agent, which is easily soluble in water and increases the deposition potential. It is known that condensation products of aldehydes and amines are good brighteners than single aldehydes or amines in the bath solution (Kariyanna et al 2003; Kariyanna and Venkatesha 2005). This may be due to the presence of $\mathrm{C}=\mathrm{N}$-group in the molecule. Various amines and aldehydes were subjected to condensation reaction (Chen and Martell 1987; Hoss and Elias 1993; AshassiSorkhabi et al 2005) and studied in a basic zinc sulphate bath. Among these, the condensation product formed between GGL and FFL is effective in getting quality deposit.

\section{Experimental}

The chemicals used were of AR grade and easily soluble in water. For the preparation of solutions, distilled water was used. The standard $267 \mathrm{~mL}$ Hull cell was used to optimize the bath constituents. The Hull cell experiments with the bath solutions (table 1) were carried out without agitation. The $\mathrm{pH}$ of the solution was adjusted with $10 \%$ sulphuric acid or sodium carbonate solution. Zinc metal of $99.99 \%$ purity was used as anode. The anode was activated each time by immersing in $10 \% \mathrm{HCl}$ followed by water wash. Mild steel plates (AISI-1079) of standard Hull cell size were mechanically polished to obtain smooth surface and degreased by dipping in boiling trichloroethylene. The scales and dust on steel plates were removed by dipping in $10 \% \mathrm{HCl}$ solution and were subjected to 
Table 1. Basic bath composition and operating conditions.

\begin{tabular}{lcl}
\hline Bath composition $\left(\mathrm{gL}^{-1}\right)$ & Quantity & \multicolumn{1}{c}{ Operating conditions } \\
\hline $\mathrm{ZnSO}_{4} \cdot 7 \mathrm{H}_{2} \mathrm{O}$ & 200 & Anode: zinc metal $(99 \cdot 99 \%)$ \\
$\mathrm{Na}_{2} \mathrm{SO}_{4}$ & 40 & Cathode: mild steel \\
$\mathrm{H}_{3} \mathrm{BO}_{3}$ & 30 & Temperature: $293-303 \mathrm{~K}$ \\
$\mathrm{CTAB}$ & 1 & Cell current: $2 \AA$ \\
EDTA & 10 & \\
\hline
\end{tabular}

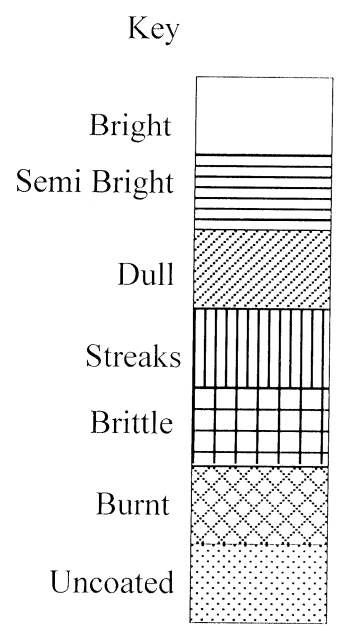

(a)

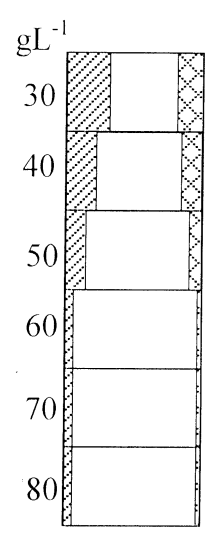

(f)

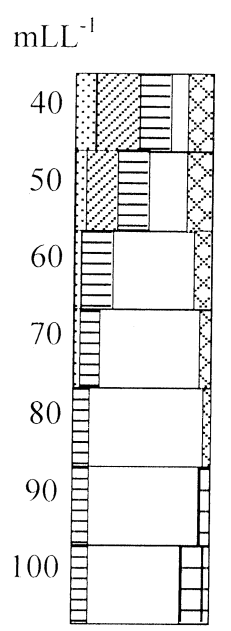

(b)

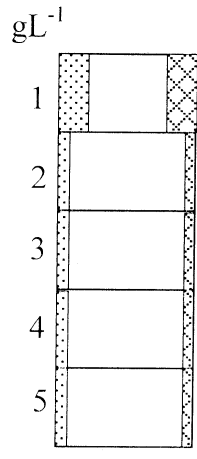

(c)

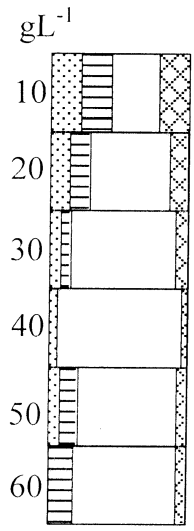

(d)

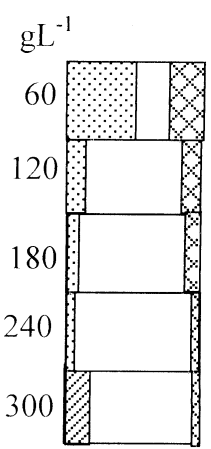

(e) $p \mathrm{H}$

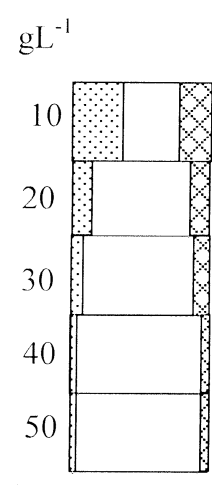

(g)

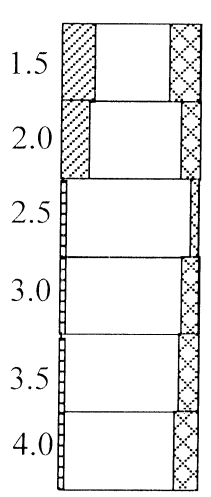

(h)

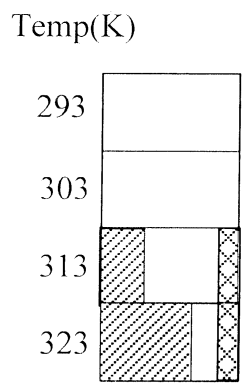

(i )
$\operatorname{Current}(\mathrm{A})$

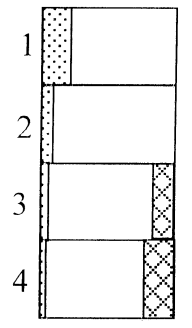

(j)

Figure 1. Hull cell figures. (a) Key, (b) effect of condensation product, (c) effect of CTAB, (d) effect of EDTA, (e) effect of $\mathrm{ZnSO}_{4}$, (f) effect of $\mathrm{Na}_{2} \mathrm{SO}_{4}$, (g) effect of $\mathrm{H}_{3} \mathrm{BO}_{3}$, (h) effect of $\mathrm{pH}$, (i) effect of temperature and $(\mathrm{j})$ effect of cell current.

electrocleaning process. Then these steel plates were washed with water and used for experiments as such. After the plating experiment, the plates were subjected to bright dip in $1 \%$ nitric acid for $2 \mathrm{~s}$ followed by water wash. The nature and appearance of zinc plating was carefully studied and recorded through the Hull cell codes (figure 1a).

All experiments were conducted at $303 \pm 1 \mathrm{~K}$. Known amount of condensation product was added to the plating bath, the bath solution was stirred for $30 \mathrm{~min}$ and then used for Hull cell experiments. Condensation product was synthesized from equimolar amounts of GGL $(1 \mathrm{~g})$ with chemical formula, $\mathrm{C}_{4} \mathrm{H}_{8} \mathrm{~N}_{2} \mathrm{O}_{3}$ (AR grade, Sisco-chem industries, Mumbai, India) and FFL $(0.6267 \mathrm{ml})$ with chemical formula, $\mathrm{C}_{5} \mathrm{H}_{4} \mathrm{O}_{2}$ (AR grade, s.d. Fine Chemicals, Mumbai, India), in ethanol media $(20 \mathrm{~mL})$, under reflux conditions for $3 \mathrm{~h}$ at $343 \mathrm{~K}$ (Chen and Martell 1987; Hoss and Elias 1993; Ashassi-Sorkhabi et al 2005). The resulting dark red product was diluted to $100 \mathrm{~mL}$ with distilled water 
and a known amount of this solution was added to the electroplating bath solution.

The deposits were obtained at constant current density from the optimized solution taken in a rectangular methacrylate cell of $2.5 \mathrm{~L}$ capacity. Polished, degreased and electro cleaned cathodes of $3 \times 4 \mathrm{~cm}^{2}$ were used for plating. Experiments were done in triplicate. Standard experimental procedures (Parthasaradhy 1989) were adopted for the measurement of metallurgical properties of the deposit such as ductility, hardness, adherence etc. In all the above studies the average thickness of the deposit was $20 \mu \mathrm{m}$. The coating thickness was measured by using $\beta$-ray back scattering gauge (Permascope ESD9, West Gut-ESD9 KB4, $220 \times 50-60 \mathrm{~Hz}$, Germany) and BNF Jet methods.

For corrosion resistance test the coated steel plates of $3 \times 4 \mathrm{~cm}^{2}$ area were given bright dip followed by passivation in a solution containing $200 \mathrm{gL}^{-1}$ of sodium chromate and $2 \mathrm{mLL}^{-1}$ of sulphuric acid at $303 \mathrm{~K}$ for $5 \mathrm{~s}$. These passivated samples were dried for $24 \mathrm{~h}$ in a clean atmosphere and subjected to neutral salt spray test in accordance with ASTM standard method B-117 using 5\% neutral sodium chloride solution at $303 \mathrm{~K}$.

Polarization studies were carried out by using a threecompartment cell. The area of zinc anode was $2 \mathrm{~cm}^{2}$. Mild steel was used as cathode with an exposed area of $2 \mathrm{~cm}^{2}$. The cathode potential was recorded galvanostatically with respect to saturated calomel electrode, at different current densities.

Haring and Blum cell was used to measure throwing power of the bath solution and a rectangular methacrylate cell was used to measure current efficiency. For throwing power measurement the current distribution ratio between anode and cathode was $1: 5$; for determining consumption of brightener, a rectangular cell of $2.5 \mathrm{~L}$ capacity was used.

The more useful method for measuring microhardness involved making an indentation with an indenter of specified geometry under specified load. The length of indentation was measured and microhardness calculated (Vickers hardness tester, British make). The value was expressed in Vickers hardness number (VHN). Zinc thickness of $20 \mu \mathrm{m}$ and load of $50 \mathrm{~g}$ was employed.

IR spectrum of the scrapped deposit was taken to ascertain the inclusion of addition agents. SEM photomicrographs were taken to ascertain the nature of deposit in the presence of addition agents.

To ascertain the amount of addition agents consumed in the bath, $2.5 \mathrm{~L}$ of bath solution was taken and plating was carried out at different current densities. The total number of coulombs passed to the bath solution was recorded at the time when the bath just started to give semibright deposit. The bath solution after use was subjected to Hull cell test by adding different amounts of condensation product. The concentration of the condensation product, at which once again bright deposit was obtained, was determined.

\section{Results and discussion}

\subsection{Hull cell studies}

3.1a Effect of condensation product: Basic bath solution gave coarse dull deposit between the current density range of 1 and $7 \mathrm{Adm}^{-2}$ at $2 \mathrm{~A}$ cell current. To improve nature of the deposit, condensation product formed between GGL and FFL was added to the bath solution. The Hull cell panels showing the effect of condensation product is shown in figure $1 \mathrm{~b}$. At lower concentration $\left(<30 \mathrm{mLL}^{-1}\right)$ of the condensation product, the deposit was semi-bright between the current density range of 1 and $7 \mathrm{Adm}^{-2}$. At lower current density, dull and at higher current density, burnt deposits were obtained. With increase in concentration, nature of the deposit was improved and at a concentration of $80 \mathrm{mLL}^{-1}$ of the condensation product, the Hull cell panels were bright between the current density ranges of 0.5 and $8 \mathrm{Adm}^{-2}$. With further increase in the concentration of the condensation product, nature of the deposit became brittle at higher current density region. Therefore, on the basis of the above observations the concentration of the condensation product was kept at $80 \mathrm{mLL}^{-1}$ as optimum.

3.1b Effect of CTAB: The concentration of CTAB was varied from $1-5 \mathrm{gL}^{-1}$ (figure 1e). At low concentration $\left(<2 \mathrm{gL}^{-1}\right)$, bright deposit was observed in the current density region between 1 and $6 \mathrm{Adm}^{-2}$. In the low current density region, dull and at high current density region, burnt deposits were obtained. With increase in the concentration of $\mathrm{CTAB}$, the brightness range was extended to high and low current density regions. At a concentration of $2 \mathrm{gL}^{-1}$ satisfactory bright deposit was obtained in the current density range of $0.5-8 \mathrm{Adm}^{-2}$ at $2 \mathrm{~A}$ cell current. With increase in the concentration of CTAB above $2 \mathrm{gL}^{-1}$ no improvement in the nature of deposit was observed. The concentration of CTAB was fixed at $2 \mathrm{gL}^{-1}$ as optimum.

3.1c Effect of EDTA: The effect of EDTA on Hull cell cathodes at $2 \mathrm{~A}$ cell current is shown in figure $1 \mathrm{~d}$. The concentration of EDTA was varied from $10-50 \mathrm{gL}^{-1}$. At low concentration of EDTA $\left(<40 \mathrm{gL}^{-1}\right)$, the deposit was bright in the current density region $0 \cdot 1-5 \mathrm{Adm}^{-2}$. At a concentration of $40 \mathrm{gL}^{-1}$, bright deposit was obtained over the entire current density region $\left(0 \cdot 5-8 \mathrm{Adm}^{-2}\right)$. But above $40 \mathrm{gL}^{-1}$ of EDTA, no improvement in the nature of the deposit was observed. Therefore, the concentration of EDTA was fixed at $40 \mathrm{gL}^{-1}$ as optimum.

3.1d Effect of zinc sulphate: To find out the effect of zinc metal ion concentration, zinc sulphate concentration was varied from $50-300 \mathrm{gL}^{-1}$. At lower concentrations, bright deposit was observed in the current density range between 2 and $6 \mathrm{Adm}^{-2}$ (figure 1e). At lower current density region, uncoated and at higher current density region, burnt deposits were obtained. With increase in the con- 
centration of zinc sulphate, the brightness range was extended to higher and lower current density regions. At a concentration of $240 \mathrm{gL}^{-1}$, satisfactory bright deposit was obtained in the current density range $1-8 \mathrm{Adm}^{-2}$ at $2 \mathrm{~A}$ cell current. With further increase in the concentration of zinc sulphate no improvement in the nature of deposit was observed. The concentration of zinc sulphate was fixed at $240 \mathrm{gL}^{-1}$ as optimum.

3.1e Effect of sodium sulphate: Sodium sulphate was added to increase the conductance of the bath solution. The Hull cell patterns showing the effect of sodium sulphate are shown in figure 1f. The concentration of sodium sulphate was varied from $20-80 \mathrm{gL}^{-1}$. At lower concentrations, the Hull cell panels suffer burnt deposit at higher current density region and dull at lower current density region. The burnt and dull regions were found to be reduced and at $60 \mathrm{gL}^{-1}$ of sodium sulphate in the bath solution, the deposit was bright over the current density range 1-8 $\mathrm{Adm}^{-2}$. Further increase in the concentration did not introduce any effect on the nature of the deposition. So the concentration of sodium sulphate was fixed at $60 \mathrm{gL}^{-1}$ in the bath solution.

3.1f Effect of boric acid: The aim of boric acid addition to the electroplating bath is to control the variation of $\mathrm{H}^{+}$ ion concentration in the bath solution. To see the optimum concentration of boric acid, the concentration was varied from $10-50 \mathrm{gL}^{-1}$, keeping the concentrations of zinc sulphate and sodium sulphate at $240 \mathrm{gL}^{-1}$ and $60 \mathrm{gL}^{-1}$, respectively. The Hull cell patterns showing the effect of boric acid are shown in figure $1 \mathrm{~g}$. Lower concentration of boric acid $\left(5-10 \mathrm{gL}^{-1}\right)$ gave bright deposit in the current density range $0 \cdot 5-4.5 \mathrm{Adm}^{-2}$. Higher concentration of boric acid (35-40 $\mathrm{gL}^{-1}$ ) gave mirror bright deposit in the current density range $0 \cdot 5-8 \mathrm{Adm}^{-2}$. The concentration of boric acid was fixed at $40 \mathrm{gL}^{-1}$ as optimum bath solution.

3.1g Effect of $p H$ : To study the effect of $\mathrm{pH}$, bath $\mathrm{pH}$ was varied from 1-4 (figure 1h). At higher $\mathrm{pH}$ (between 2.5 and 4) the Hull cell panels showed burnt deposit at high current density range. At $\mathrm{pH} 2.5$ satisfactory bright deposits were obtained. At still lower $\mathrm{pH}(<2 \cdot 5)$, the specimen contained uncoated area at low current density region and burnt at high current density region. From the above observation, $\mathrm{pH}$ of the bath solution was kept at $2 \cdot 5$ as optimum.

3.1h Effect of temperature: To know the effect of temperature on Hull cell experiments, plating experiments were carried out in a thermostat. The temperature of the thermostat was varied from 293-323 K. The Hull cell panels showing the effect of temperature are shown in figure 1i. At lower temperature $(<303 \mathrm{~K})$, the deposition was bright in the current density range between 1 and $8 \mathrm{Adm}^{-2}$ at $2 \mathrm{~A}$ cell current. Above $308 \mathrm{~K}$ the deposition was dull in low current density range. So the optimum temperature range was 293-303 K.

3.1i Effect of cell current: The Hull cell experiments were carried out at different cell currents (1-4 A) for 5 min using optimum bath solution. The Hull cell patterns are shown in figure $1 \mathrm{j}$. It was found that at a cell current of $1 \mathrm{~A}$ the deposit was bright in the current density range of 0-4 $\mathrm{Adm}^{-2}$. At a cell current of $2 \mathrm{~A}$, the deposit was bright in the current density range of $0 \cdot 5-8 \mathrm{Adm}^{-2}$. At cell currents of $3 \mathrm{~A}$ and $4 \mathrm{~A}$ the Hull cell panels showed burnt deposit at current density higher than $8 \mathrm{Adm}^{-2}$. This observation revealed that the bath gave bright deposit in the current density range $0 \cdot 5-8 \mathrm{Adm}^{-2}$.

\subsection{Current efficiency and throwing power}

Current efficiency and throwing power were measured at different current densities by using optimized bath solution. At $1.0 \mathrm{Adm}^{-2}$, the current efficiency was found to be $92 \%$. At a current density of $2 \mathrm{Adm}^{-2}$, the current efficiency was found to be $95 \%$. With increase in the current density above $3 \mathrm{Adm}^{-2}$, the current efficiency was found to be decreased and at $5 \mathrm{Adm}^{-2}$ it was $89 \%$.

Table 2. Current efficiency and throwing power for optimum bath solution at different current densities.

\begin{tabular}{lcc}
\hline $\begin{array}{l}\text { Current density } \\
\left(\mathrm{Adm}^{-2}\right)\end{array}$ & $\begin{array}{c}\text { Current efficiency } \\
(\%)\end{array}$ & $\begin{array}{c}\text { Throwing power } \\
(\%)\end{array}$ \\
\hline 1 & 92 & 26 \\
2 & 95 & 29 \\
3 & 93 & 23 \\
4 & 92 & 23 \\
5 & 89 & 21 \\
\hline
\end{tabular}

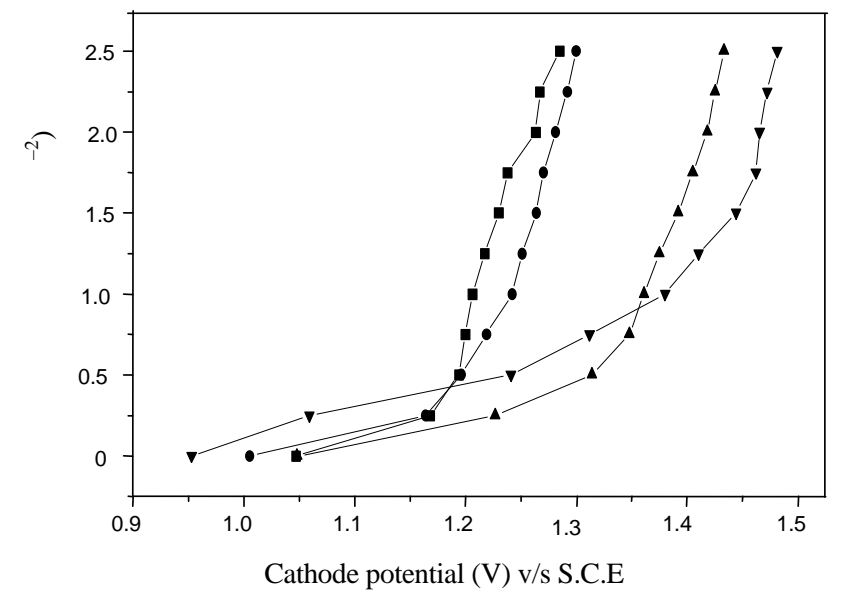

Figure 2. Effects of addition agents on cathodic potential $\{\mathbf{\square}$, $\mathrm{ZnSO}_{4}\left(240 \mathrm{gL}^{-1}\right)+\mathrm{Na}_{2} \mathrm{SO}_{4}\left(60 \mathrm{gL}^{-1}\right)+\mathrm{H}_{3} \mathrm{BO}_{3}\left(40 \mathrm{gL}^{-1}\right)[\mathrm{BB}]$; -, $\mathrm{BB}+\mathrm{CTAB}\left(2 \mathrm{gL}^{-1}\right) ; \boldsymbol{\Delta}, \mathrm{BB}+\mathrm{CTAB}+\mathrm{EDTA}\left(40 \mathrm{gL}^{-1}\right)$; $\left.\boldsymbol{\nabla}, \mathrm{BB}+\mathrm{CTAB}+\mathrm{EDTA}+\mathrm{GGL}-\mathrm{FFL}\left(80 \mathrm{mLL}^{-1}\right)\right\}$. 
Throwing power of bath was measured using Haring and Blum cell at different concentrations of the bath constituents under different operating conditions. The variation of throwing power at different current densities is given in table 2. The throwing power is noticed in the range 21$29 \%$.

\subsection{Polarization studies}

The potential of the steel cathode was measured galvanostatically with respect to saturated calomel electrode at different current densities. The variation of potential in the presence of different bath constituents is shown in figure 2 . The shift in cathodic potential towards negative direction was observed in presence of addition agents.

\subsection{Surface morphology and IR studies}

The nature of crystal growth in the presence and absence of addition agents is explained with the help of SEM photomicrographs (figure 4). In figure $4 \mathrm{a}$, the crystal growth is not uniform, the basic bath produced a deposit having different and slightly larger crystal sizes. SEM photomicrographs of the deposit obtained from the optimized bath showed a uniform arrangement of the crystals, refinement in the crystal size and hence gave a bright deposit (figure 4d). SEM image of the passivated deposit obtained from the optimized bath is shown in figure $4 \mathrm{e}$.

The IR spectrum of the scrapped deposit obtained from the optimized bath was used to determine inclusion of an organic compound in the deposit. The IR spectrum (figure 3) contains peak at $3422 \mathrm{~cm}^{-1}$ which corresponds to

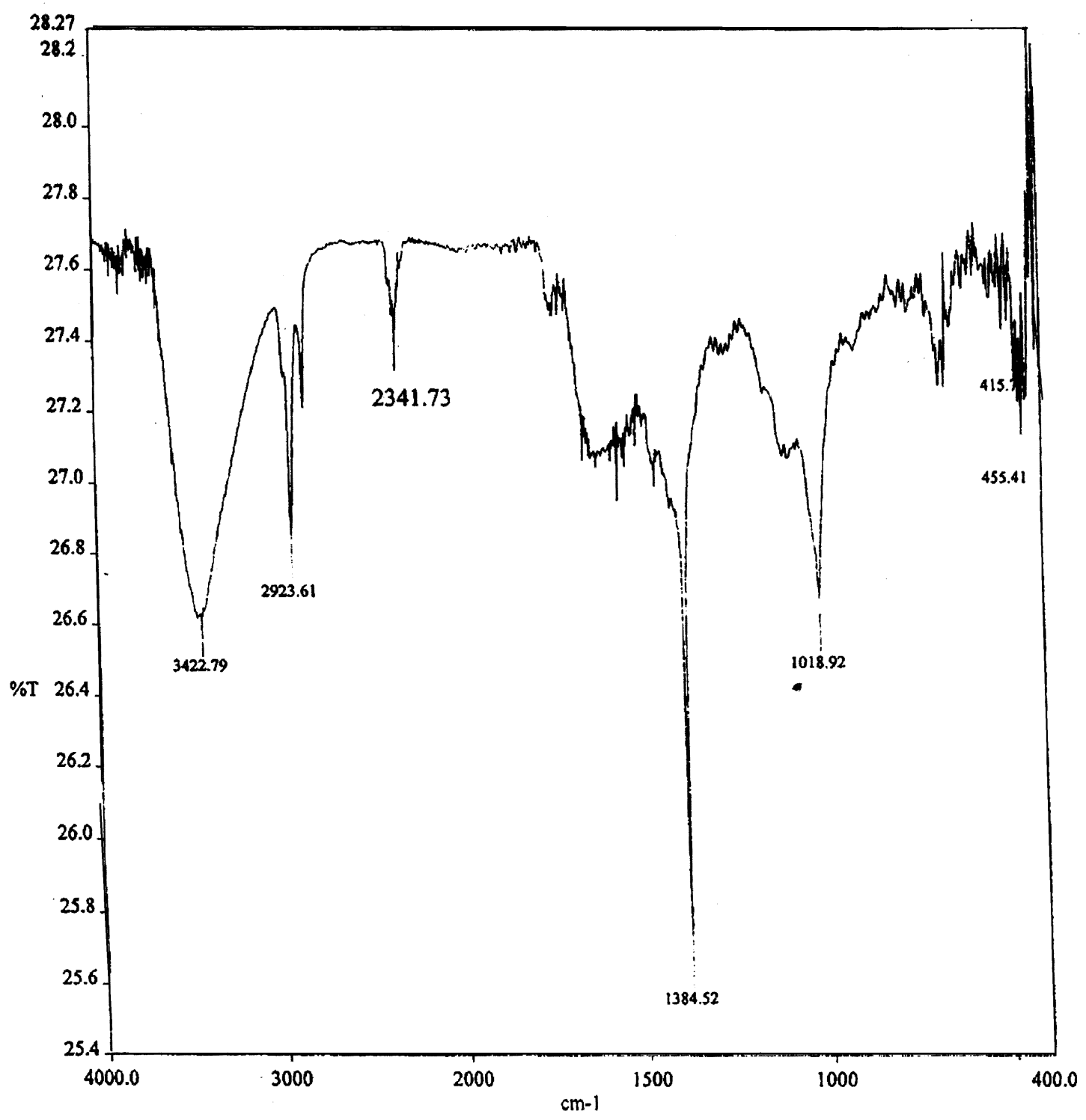

Figure 3. IR spectrum of the scrapped zinc deposit. 

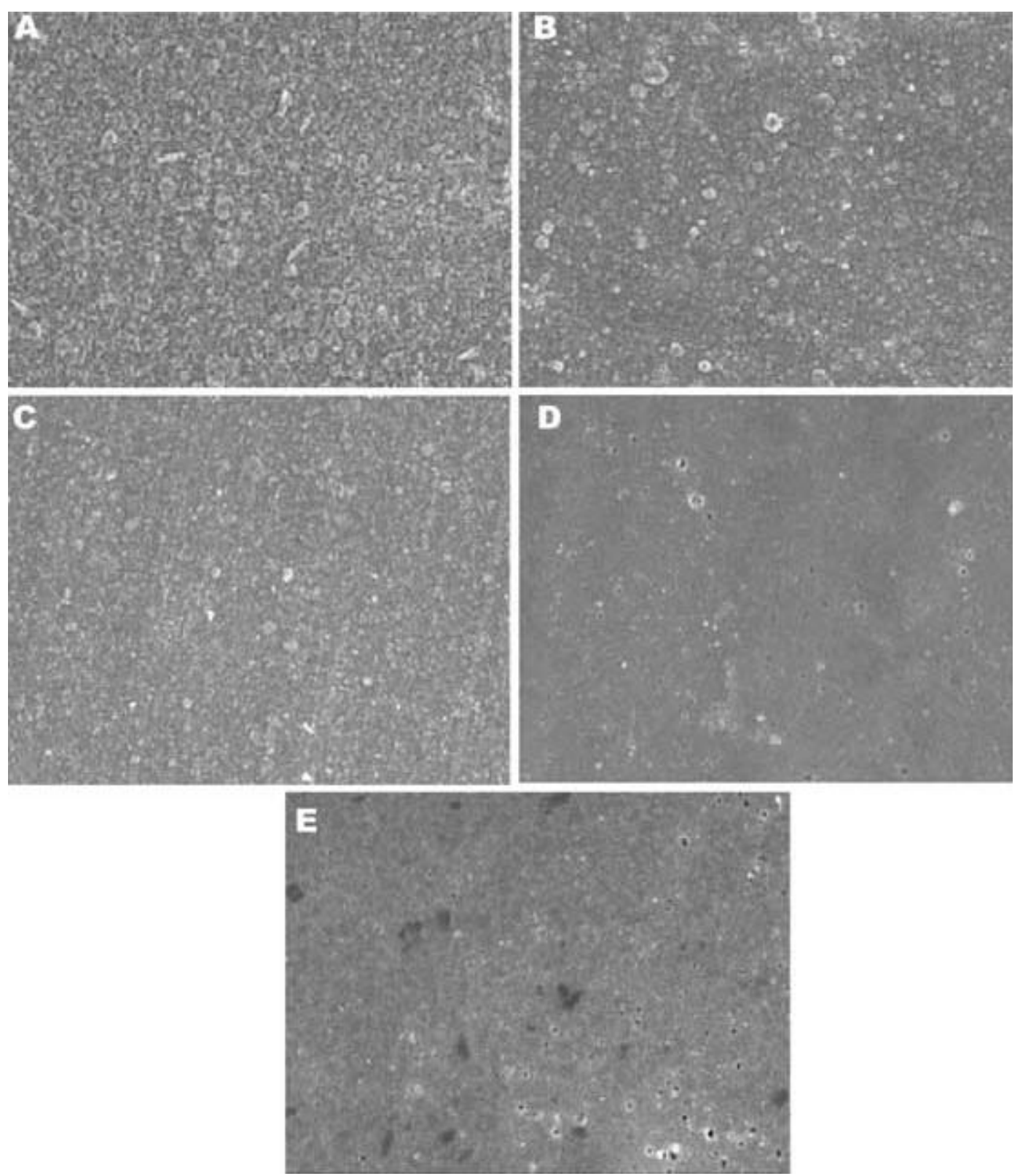

Figure 4. SEM photomicrographs of the deposits obtained at $2 \mathrm{Adm}^{-2}$ in the presence and absence of addition agents at $298 \mathrm{~K}$ : A. basic bath (BB), B. BB + CTAB, C. BB + CTAB + EDTA, D. optimized bath and E. passivated deposit.

$\mathrm{N}-\mathrm{H}$ stretching. Peak at $1384 \mathrm{~cm}^{-1}$ corresponds to $\mathrm{C}-\mathrm{N}$ stretching frequency. The absorption peaks in the IR spectrum revealed inclusion of addition agent in the deposit during electrodeposition.

\subsection{Corrosion resistance}

For corrosion resistance study, steel cathodes were given deposit of varying thicknesses from 5-25 $\mu \mathrm{m}$. The specimens after plating were subjected to bright dip in $1 \%$ nitric acid followed by passivation. The porosity of the deposit was tested with potassium ferricyanide paper. The soaked paper with potassium ferricyanide was placed on the deposit and no blue spots were observed. This test indicated pore free nature of the deposit. Further corrosion resistance test was carried out in a salt spray chamber. The deposited plates, after passivation, were subjected to continuous spray of neutral $5 \%$ sodium chloride solution. The deposit did not show any rust even after $96 \mathrm{~h}$ of testing. The plates deposited from basic bath solution without passivation showed white rust within $24 \mathrm{~h}$ and the deposits from the optimum bath showed white rust after $72 \mathrm{~h}$. This study shows good resistance of the deposit. 
Table 3. Optimum bath composition and operating conditions.

\begin{tabular}{lcl}
\hline Bath composition & Quantity & \multicolumn{1}{c}{ Operating conditions } \\
\hline $\mathrm{ZnSO}_{4} \cdot 7 \mathrm{H}_{2} \mathrm{O}\left(\mathrm{gL}^{-1}\right)$ & 240 & Anode: zinc metal $(99.99 \%)$ \\
$\mathrm{Na}_{2} \mathrm{SO}_{4}\left(\mathrm{gL}^{-1}\right)$ & 60 & Cathode: mild steel \\
$\mathrm{H}_{3} \mathrm{BO}_{3}\left(\mathrm{gL}^{-1}\right)$ & 40 & Temperature: $293-303 \mathrm{~K}$ \\
$\mathrm{CTAB}_{\left(\mathrm{gL}^{-1}\right)}$ & 2 & Bright current density range: $0 \cdot 5-8 \mathrm{Adm}^{-2}$ \\
EDTA $\left(\mathrm{gL}^{-1}\right)$ & 40 & Agitation: air \\
Condensation product & 80 & \\
(GGL-FFL) (mLL & \\
\hline
\end{tabular}

\subsection{Metallurgical properties}

Standard bend test was used to measure bath adherence and ductility of zinc deposits. Mild steel panels of $1 \mathrm{~mm}$ thick $\left(1 \times 10 \mathrm{~cm}^{2}\right.$ area) were electroplated with zinc to different thicknesses $(5-20 \mu \mathrm{m})$. The samples were subjected to bending through $180^{\circ}$. No crack or peel off in the deposit was noticed even after $180^{\circ}$ bending of the specimen. This indicates good adherence and ductility of zinc deposit on steel. The microhardness of zinc was found to be 130 VHN.

\subsection{Consumption of brightener}

The amount of condensation product consumed for 1000 amp-h was $7 \mathrm{mLL}^{-1}$.

\subsection{Scaling up study}

The commercial applicability of the developed bath was explored by performing plating experiments in a vat of $25 \mathrm{~L}$ capacity. The bath solution with optimum concentration of bath constituents was prepared. Steel components of different sizes and shapes (plates, rods, nuts, bolts, small pipes, clamps etc) were degreased, electrocleaned and given acid dip followed by water wash. These treated components were rigged by copper wire and connected to the negative terminal of the d.c. source. Electroplating was carried out at different current densities (2-8 $\mathrm{Adm}^{-2}$ ) with and without agitation of the bath solution. The components after deposition were removed from the plating vat and subjected to bright dip and passivation. The passivated articles were subjected to corrosion resistance test in salt spray chamber. Adhesion of the deposit to the substrate was good as it was confirmed by bend test and heat test methods (Parthasaradhy 1989). The components of irregular shapes plated under stirred and unstirred conditions showed no rust at recesses even after $96 \mathrm{~h}$ of salt spray test. This indicated the ability of the bath to produce uniform deposit on the component having irregular shape.
The anode dissolution efficiency was $99 \cdot 8 \%$. The decrease in metal ion concentration for $1000 \mathrm{amp}-\mathrm{h}$ was determined and it was $1.5 \mathrm{gL}^{-1}$. This was replenished by adding equivalent amount of zinc sulphate to the bath solution.

\section{Conclusions}

The optimum bath is capable of producing bright deposit over a wide current density range. The throwing power was reasonably good. The brightener can be easily synthesized. The addition agents are non-toxic, easily soluble in water and hence require no treatment of the effluent. The deposit is pore free and corrosion resistant. The bath could be easily commercialized.

\section{References}

Arthoba Naik Y and Venkatesha T V 2005 Bull. Mater. Sci. 28 495

Arthoba Naik Y, Venkatesha T V and Vasudeva Nayak P 2002 Trans. SAEST 3739

Arthoba Naik Y, Venkatesha T V and Vasudeva Nayak P 2001 Indian J. Chem. Technol. 8390

Ashassi-Sorkhabi H, Shaabani B and Seifzadeh D 2005 Electrochimica Acta $\mathbf{5 0} 3446$

Ashur A, Sharon J and Klein I E 1996 Plat. Surf. Finish. 8358

Baldwin K R and Smith C J E 1996 Trans. Inst. Met. Finish. 74 202

Chen D and Martell A E 1987 Inorg. Chem. 261026

Hoss H and Elias H 1993 Inorg. Chem. 23317

Kariyanna K G and Venkatesha T V 2005 B. Electrochem. 21 547

Kariyanna K G, Arthoba Naik Y and Venkatesha T V 2003 J. Indian Council of Chemists 2043

Parthasaradhy N V 1989 Practical electroplating handbook (New Jersey: Prentice Hall Inc) 1st ed., pp 283 \& 294

Safranck W H 1997 Plat. Surf. Finish. 8545

Senthil Kumar A, Senthil Raja Pandian C, Ayyapparaju J and Ramesh Bapu G N K 2001 B. Electrochem. 17379

Swathirajan S 1986 J. Electrochem. Soc. 133671

Veeraraghavan B, Haran B, Prabhu S and Popov B $2003 \mathrm{~J}$. Electrochem. Soc. 150 B131 